\title{
PART 2. \\ METROPOLITAN ANDREY SHEPTYTSKY THROUGH THE EYES OF CONTEMPORARIES AND IN THE HISTORIOGRAPHY
}

A large number of works about Metropolitan Andrey Sheptytsky came out abroad, works, in which their authors tried to trace the major milestones in his life, to show the role of Sheptytsky in raising the national and cultural level of the Ukrainians, especially those who lived in Western Ukraine, to analyze his views, versatile educational, cultural, ecumenical and political activity. Foreign historians had the opportunity to express their views freely, which could not be said about the researchers, who published their works within the Soviet Union. Considering the fact that several hundred works have been published about Sheptytsky's life and work, we will view only some of them.

The ecumenism of Andrey Sheptytsky has been studied by many historians and even by his contemporaries. However, a special attention should deserve a doctoral dissertation of His Beatitude Lubomyr Husar, defended by him in 1972 at the Pontifical Urban University. L. Husar mentioned: "Metropolitan Sheptytsky belonged to the few people, who, being upset by the discord between Christians at the beginning of the twentieth century, worked to change somehow such a tragic situation (the split in the Christian movement - Aut.), acted at random, without any guidelines or official instructions, guided by their own beliefs and wishes of union, which, of course, affected the nature of their activities... Today, after the time interval... we can highly appreciate the essential role of those pioneers, among which Metropolitan Sheptytsky was, without exaggeration, the most prominent" ${ }^{\prime 65}$. Metropolitan's ecumenical activity was praised by Vasyl Lentsyk: "From this angle one must understand all the activities of Andrey Sheptytsky, his tireless work in the direction of the ecclesial unity of all Christians, and the Ukrainian people in particular, in one Christ Church. In this work on unification Metropolitan saw a special role and mission of the Ukrainian people... Metropolitan Andrey realized what misfortune was a Church break-up for our people, in addition a part of our Church, both in Tsarist and the Bolsheviks period Russia, was used to the detriment of the Ukrainian people. Considering the conditions of the Ukrainian people, he

65 Гузар Любомир. Андрей Шептицький Митрополит Галицький (1901-1944) провісник екуменізму / Видання друге. Жовква: Місіонер, 2015. С. 23. 
believed that Ukrainians, more than anyone else, have a mission to work for unification. Unfortunately, this very important case even now is underestimated" ${ }^{\prime 66}$.

Famous English theologian and church historian J. Pelikan, anallyzing A. Sheptytsky's work from the point of view of today, wrote: "Andrey Sheptytsky's ideas of unification were theologically meaningful and historically fascinating. It is safe to say that he was one of those, who worked hard to make the unification of the Universal Church come true. His great merit is that now, after the Second Vatican Council, the prospects of understanding between East and West are better than ever in the previous centuries. Everything points to the fact that the most difficult antagonistic and doctrinal cases that have remained unchanged for 1,000 years, could be solved today. It was once a great vision for which Metropolitan Andrey Sheptytsky dedicated his entire life" ${ }^{\text {"67 }}$. One of the closest associates of Metropolitan, Kyrylo Korolevych (Paul Francois Sharon) thoroughly described the activity of Sheptytsky in Russia, and it is evidenced by at least the titles of the chapters ("Private visit to Russia", "Father Ivan Deibner", "Father Olexii Zerchaninov", "Pius X confirms the authority of Metropolitan", "Parish in St. Petersburg", "Father Leonid Fyodorov", "Russian Greek-Catholic Synod, Petrograd in 1917", "Russian Greek Catholic Exarch", "Renaissance of the Russian Orthodox Church", "persecution of the religion", "Greek Catholic Community in Moscow", "other Greek Catholics in Russia", etc.). K. Korolevsky expressed Metropolitan's intentions in Russia in his own words: "I am Metropolitan Sheptytsky, I offer you my mediation to establish contact with Rome" ${ }^{\text {. }}$. A. Sheptytsky's diplomatic missions were described by Josyf Slipyi in his "Memories" ${ }^{\circ 9}$. In the Ukrainian historical science the ecumenical activity of Metropolitan was researched by V. Basarab, O. Khomenko, E. Bystrytska, J. Bilas, M. Vavzhonek, H. Hladka, L. Krupa, M. Marynovych, A. Smyrnov, O. Surmach, O. Sheremeta and others. ${ }^{70}$

66 Ленцик Василь. Визначні постаті Української Церкви: Митрополит Андрей Шептицький і Патріярх Йосиф Сліпий. Львів: Свічадо, 2004. С. 269.

${ }^{67}$ Morality and Reality. The life and times of Andrei Sheptytskyi / Paul Robert Magocsi, editor with the assistance of Andrii Krawchuk. Canadian Institute of Ukrainian Studies University of Alberta Edmonton 1989. P. 10-11.

${ }^{68}$ Королевський Кирило. Митрополит Андрей Шептицький (1865-1944) / пр. 3 фр. Я. Кравець / Вид. 2-ге, випр. Львів: Свічадо, 2016. С. 239.

${ }^{69}$ Сліпий Йосиф. Спомини / ред. Іван Дацько, Марія Горяча, вид. 3-тє, виправлене й доповнене. Львів - Рим: Видавництво УКУ, 2017. С. 114-115.; Див.: Матеріяли до історії українського патріархального руху / Упор. А. Сороковський. Львів: Свічадо, 2009. 364 с.

70 Басараб В. Проблема єдності Церков у світлі екуменічних ідей митрополита А.Шептицького. Матеріали міжнародної науково-практичної конференції Волинської 
Among the special works that analyzed the life and activities of Andrey Sheptytsky, one should mention the work of Vasyl Laba, the first edition of which appeared in 1965. Some sections of his work are titled this way: "Boyar ancestry of Sheptytsky", "The boyish and school age of the future Metropolitan Andrey", "An important decision of Dr. Roman Olexandr Earl Sheptytsky", "Roman Sheptytsky as the Basilian monk", "Andrey Sheptytsky as a Stanislaw Bishop", "Bishop Andrey Sheptytsky as Metropolitan of Galicia", "Metropolitan Andrey - Kniaz of the Ukrainian Church", "He who prays for his brothers". This list of sections of V. Laba's work testifies to the comprehensive coverage of the life of Metropolitan. However, the author himself considered his research a modest job. In the preface to the book, V. Laba wrote: "The full biography of Metropolitan can be arranged no sooner than when the title of that biography will sound "The life of St. Andrey, Great Metropolitan of Galicia". All that will be written about him by that time is just the little parts that future hagiographer will bring into one. I confine myself to recording in order the most important events in the life of Metropolitan, and I'm weaving a canvas for the network

православної богословської академії УПЦ КП «Державотворення і помісність Церкви: історичні процеси та сучасні реалії» (18.05.2017). Луцьк: Видавництво Волинської православної богословської академії $\mathrm{EIK} \Omega N$, 2017. С. 27-34; Бистрицька Е. Українське православ'я та екуменічна діяльність митрополита Андрея Шептицького в роки Другої світової війни. Українське релігієзнавство. 2002. № 23. С. 45-55; Білас Я. І. Екуменізм Андрея Шептицького і проблема суверенності нації. Історія релігій в Україні. Кн. 1. Львів, 1999. С. 45-48; Вегеш М. М., Хоменко О. В. Екуменічні ідеї митрополита Андрея Шептицького та діяльність по їх реалізації. Carpatica-Карпатика: Актуальні проблеми політичного та етнокультурного розвитку Карпатського регіону в XIX-XX століттях. Ужгород: Вид-во «Два кольори», 2001. Вип.10. С.278-312; Гладка Г. Л. Берестейська унія й екуменічний процес в оцінках та діяльності А.Шептицького. Обрії. Часопис ІваноФранківського обласного інституту післядипломної освіти педагогічних працівників. Івано-Франківськ, 1996. №1(3). С.43-47; Гладка Г.Л. Екуменічна діяльність митрополита Андрея Шептицького. Добрий пастир. Часопис, присвячений церковним і богословським справам. Івано-Франківськ, 1996. Ч.1. С. 99-101; Гладка Г.Л. Проблема релігійної єдності України в унійно-екуменічній діяльності митрополита Андрея Шептицького. Наукові записки Тернопільського державного педагогічного університету ім. В. Гнатюка, Серія: Історія. Тернопіль, 1999. Вип.ІХ. С. 37-40; Крупа Л. Спроби митрополита Андрея Шептицького через ідеї екуменізму досягти фізичного та духовного об'єднання України. Наш голос. /видає Асоціація Українців Америки/, 2000. Вересень-жовтень, ч. 9-10.; Маринович М. Митрополит Андрей Шептицький і принцип «позитивної суми» / передмова Адріана Сливоцького. Львів: Видавництво Старого Лева, 2019. 248 с.; Смирнов А. Митрополит Андрей Шептицький i православ'я: від екуменізму до національної єдності. Наукові записки Національного університету «Острозька академія». Серія «Історичні науки». 2017. Вип. 26. С. 40-44; Сурмач О. Екуменічна діяльність УГКЦ в роки німецької окупації Галичини (1941-1944рр.). Київська Церква. Київ-Львів, 2000. №4 (10). С.72-78; Шеремета О. Екуменізм як етична ідея А. Шептицького. Філософ. думка. 2007. № 1. С. 60-69; Шеремета О. Ю. Екуменізм як етична ідея Шептицького. Філософська думка. №1. 2007. С. 60-68. 
of virtues, ideals and deeds of the Great Metropolitan, and that will perpetuate him in the grateful memory of the Ukrainian people. My modest sketch of the life of Metropolitan Andrey is only a statement of my modest special gratitude for him: my Tutor, Saint and long-time Hierarch",71.

The works of S. Baran and V. Doroshenko were published even earlier ${ }^{72}$. Both of these essays are similar to V. Laba's work. They analyze in general terms the main stages of life and activity of Metropolitan. Professor of University of Toronto O. Baran is the author of the number of articles on ecumenical ideas of Andrey Sheptytsky ${ }^{73}$. I. Khoma researched the role of Sheptytsky in the life of Metropolitan Josyf Slipyj ${ }^{74}$. According to N. Davis, "it is no wonder that Earl Andrey Sheptytsky, the most prominent patron of the Ukrainian national movement in Galicia and the Uniate Archbishop of Lviv since 1900, was a loving older brother of the active Polish nationalist General Stanislaw Sheptytsky"75. Ukrainian-Polish relations at the turn of the century have been researched by I. Tsependa, L. Hentosh, D. Blazheyovsky, O. Krasivsky, I. Pylypiv and other researchers ${ }^{76}$.

The famous foreign historian and political scientist I. Lysiak-Rudnytsky paid great attention to the personality of Andrey Sheptytsky. In the article "Ukrainians of Galicia under Austrian domination", he wrote that Sheptytsky was "generally recognized as one of the most prominent Slavic ecclesiastical figures of our century... It is just enough to mention that he

71 Лаба Василь. Митрополит Андрей Шептицький. Його життя і заслуги. Люблин: Свічадо, 1990. С. 13.

72 Баран С. Митрополит Андрей Шептицький: життя i діяльність. Мюнхен: Вернигора, 1947. 151 с.; Дорошенко В. Митрополит Андрей Шептицький і обєднання Церков. Логос. 1955. Т. 6. С. 137-143.

73 Баран О. Митрополит Андрей Шептицький і його екуменічні ідеї. Український Iсторик. 1-4 (120-123). Нью-Йорк - Торонто - Київ - Львів - Мюнхен, 1994.

74 Хома I. Шляхами каторги Блаженного Йосифа Сліпого. "Альманах «Гомону України». Торонто, 1995. С. 49-75.

${ }_{75}$ Дейвіс Н. Боже ігрище: історія Польщі. К.: Основи, 2008. С. 505-506.

76 Цепенда I. Українсько-польські відносини 40-50-х років XX століття: етнополітичний аналіз. К., 2009. 387 с.; Блажейовський Дмитро. Деякі сумні сторінки 3 історії України та дещо про ії сусідів: Україну краще треба нам самим будувати (Збірка особистих спостережень автора). Львів: Видавництво «Каменяр», 2007. 640 с.; Гентош Л. Митрополит Шептицький: 1923-1939. Випробування ідеалів. Львів, 2015. 596 с.; Гентош Л. Постать митрополита Шептицького в українських та польських наукових виданнях останнього десятиріччя. Україна модерна / За ред. В. Верстюка, Я. Грицака, Л. Зашкільняка, В. Кравченка, М. Крикуна. К.: Критика; Львів: Інститут історичних досліджень Львівського національного університету імені Івана Франка, 2003. Ч. 8. С. 179-210; Красівський О., Пилипів І. Митрополит Андрей Шептицький і польська держава (1918-1923рр.). Українсько-польські відносини в Галичині: матеріали Міжнародної науково-практичної конференції (21-22 листопада 1996 р.). ІваноФранківськ: Плай, 1997. С. 152-155. 
founded new monastic orders, carried out liturgical reforms and promoted theological researches. Keeping away from current politics, Sheptytsky did a great service to the Ukrainian case, tactfully using his connections in Vienna, as well as being a generous patron of the arts... Intellectually agile and conscious of the needs of the time, he encouraged the clergy to participate in public life. The fact that the Greek Catholic Church was now headed by an important person, and at the same time a distinct, bright personality, gave the Ukrainian national movement certainty in its own power. However, Sheptytsky was not a narrow-minded nationalist, but a man of a supranational vision: the idea, he devoted his life to, was a union of Western and Eastern Christianity. It envisaged respect for all the features of the Eastern religious tradition compatible with the Catholic dogma"77. On many questions, the solutions of which were vitally important for the Ukrainians of Eastern Galicia, Andrey Sheptytsky took a compromise position $^{78}$. In the work "Ukrainian National Movement" I. Lysyak-Rudnitsky once again returns to the figure of Andrey Sheptytsky. According to him, "under the leadership of a prominent figure - Andrey Sheptytsky, Metropolitan of Galicia since 1900, the Greek Catholic Church became closely linked to Ukraine's struggle for independence"79. It is necessary to agree with such considerations.

The figures of the Ukrainian People's Republic, Lonhyn Tsehelsky and Volodymyr Vynnychenko, hoped strongly for the support of Andrey Sheptytsky. I. Lysyak-Rudnytsky describes an interesting episode on the pages of his serious work "Volodymyr Vynnychenko's Social and Political Worldview": "When Tsehelsky noted that such a move (to make Metropolitan the head of the All-Ukrainian Church - Aut.) would mean a break with the Orthodoxy, Vynnychenko immediately replied: "We will abolish Orthodoxy! It brought us under the eastern king, it led us through the russification of Ukraine. Orthodoxy will always gravitate to Moscow. Your (Galician) union is good for distinguishing yourself from Poland and from Moscow. The Uniate, because of his nature, becomes a (nationally conscious) Ukrainian. We will convene a synod of bishops, archimandrites and representatives of lay people from Ukraine and we'll advise them to accept the union (of the churches) and put Sheptytsky in the forefront. Let's

77 Лисяк-Рудницький Іван. Історичні есе. В 2-х тт. Т. 1. / Пер. 3 англ. М. Бадік, У. Гавришків, Я. Грицака, А. Дещиці, Г. Киван, Е. Панкеєвої. К.: Основи - Інститут державного управління та місцевого самоврядування при Кабінеті Міністрів України, 1994. C. 436-437.

${ }^{78}$ Ibid. C. 422.

${ }^{79}$ Ibid. C. 476-477. 
also get acquainted with Rome to make him the patriarch of Ukraine... Do you think I'm kidding?" 80 .

Researching the life and activities of Vyacheslav Lypynsky, I. LysyakRudnytsky also pays attention to Metropolitan of Galicia. Rightly referring Sheptytsky to the bright representatives of the Polish-Ukrainian aristocracy, a scientist wrote: "Considering the innumerable services rendered to the Ukrainian case only by this personality, one can ask himself whether the participation of more people such as Sheptytsky would not change the outcome of the Ukrainian struggle for independence from defeat to victory" $"$.

In contrast to the statements of Soviet historians, I. Lysyak-Rudnytsky rightly noted that "Sheptytsky in the questions of national importance got along with existing parties and did not consider it necessary to create a separate Catholic political organization, which was Khomyshyn's goal" ${ }^{12}$. He was "tuned, when using a terminology of later times, more ecumenically, and wanted to preserve the roots of the Eastern, Byzantine tradition in the Greek Catholic Church"83. Thus, although I. Lysyak-Rudnytsky did not write a special work on Andrey Sheptytsky, but he analyzed various aspects of his activity, gave an objective evaluation of Metropolitan of Galicia. V. Veryha, M. Kuhutiak, M. Lytvyn and other scientists, investigated national liberation struggle of Galician Ukrainians in 1918-1919 and A. Sheptytsky's participation in $\mathrm{it}^{84}$. The contribution of Metropolitan of Galicia to the

80 Лисяк-Рудницький Іван. Історичні есе. В 2-х тт. Т. 2. / Пер. з англ. У. Гавришків, Я. Грицака. К.: Основи - Інститут державного управління та місцевого самоврядування при Кабінеті Міністрів України, 1994. С. 102-103.

${ }^{81}$ Ibid. C. 163.

${ }^{82}$ Ibid. C. 215.

${ }^{83}$ Idid.

${ }^{84}$ Верига В. Визвольні змагання в Україні 1914-1923 pр. У двох томах. Т. 1. Жовква: Видавництво Отців Василіан «Місіонер», 1998. 524 с.; Верига В. Визвольні змагання в Україні 1914-1923 pр. У двох томах. Т. 2. Жовква: Видавництво Отців Василіан «Місіонер», 1998. 504 с.; Верига В. Нариси з історії України (кінець XVIII - початок ХХ ст.). Львів: Видавництво «Світ», 1996. 448 с.; Гуцуляк М. Перший листопад 1918 року на західних землях України зі спогадами і життєписами членів Комітету Виконавців Листопадового Чину. К.: Либідь, 1993. 408 с.; Західно-Українська Народна Республіка. 1918-1923: Історія / Керівник авторського колективу й відповідальний редактор Олександр Карпнко. Івано-Франківськ: Сіверсія, 2001. 628 с.; Красилівський О. За Українську державу i Церкву. Громадська та суспільно-політична діяльність Митрополита Андрея Шептицького в 1918-1923 рр. Львів, 1995. 86 с.; Красівський О. Дипломатичні місії Андрея Шептицького. Україна: ЗУНР: Історія і традииї. Л., 2000. С. 291-296; Красівський О. За Українську державу і Церкву. Громадська та суспільнополітична діяльність Митрополита Андрея Шептицького в 1918-1923 рр. Львів: Інститут українознавства ім. І. Крипякевича НАН України, 1995. 86 с.; Красівський О., Пилипів I. Митрополит Андрей Шептицький і польська держава (1918-1923рр.). Украӥнсько- 
Ukrainian state-making processes has been successfully researched for many years by V. Serhiychuk ${ }^{85}$.

An attempt to write a short biography of Andrey Sheptytsky was made by Roman Holovyn. Analyzing the main moments in the life and activity of Metropolitan of Galicia, the author noted: "I. Franko was passionate about Sheptytsky's broad activities and cultural work. He and M. Pavlyk often visited Metropolitan in scientific affairs. They were amazed of the lifestyle of the Earl- Metropolitan. He lived as an ascetic: a small room, alone in the wool black cloak of a monk-student, with a black belt, with prayer beads on his belt or in his hands, the most modest dish..." ${ }^{" 86}$. To the deep conviction of the author, Sheptytsky was always worried about "the future of the Ukrainian people. He did his best to prevent somehow the denationalization of our intelligentsia" ${ }^{\prime 87}$.

The figure of Andrey Sheptytsky takes an important place on the pages of the work on the history of church, written by I. Ortynsky. According to

польські відносини в Галичині: матеріали Міжнародної науково-практичної конференції (21-22 листопада 1996 р.). Івано-Франківськ: Плай, 1997. С. 152-155; Кугутяк М. Андрей Шептицький у національно-визвольних змаганнях українського народу. Спадщина митрополита Андрея Шептицького в національному й духовному відродженні України. Івано-Франківськ: Плай, 2000. С. 66-75; Кугутяк М. Галичина. Сторінки історії: нарис суспільно-політичного руху (ХІХ ст. - 1939). Івано-Франківськ: Плай, 1993. 202 с. ; Кугутяк М. Історія української націонал-демократії (1918-1929). Т. 1. Київ - ІваноФранківськ: Плай, 2002. 536 с.; Кугутяк М. Українська націонал-демократія (1918-1939). Т. 2. Київ - Івано-Франківськ: Нова Зоря, 2004. 704 с.; Литвин М. Науменко К. 1939. Західні землі України. Львів: Ін-т українознавства НАНУ, 1999. 152 с. ; Литвин М., Науменко К. Історія ЗУНР. Львів: Інститут українознавства НАНУ; Видавнича фірма «ОЛВР», 1995. 368 с.; Расевич В. Митрополит Андрей Шептицький і проблеми національно-політичної консолідації українців (1900-1918 роки). Ковчег. Науковий збірник із української історії / Під ред. Б. Гудзяка, І. Скочиляса, О. Турія. Львів, 2000. Ч. 11. С. 189-211; Цвенгрош Г. Митрополит Андрей Шептицький: 1918-1919. Львів: Місіонер, 1991. 38 с.; Цвенгрош Г. Митрополит на сторожі держави. Літопис Червоної калини. 1994. Ч. 1-3 (32-33). С. 2-5; Цвенгрош Г. Національно-державотворчі погляди митрополита Андрея Шептицького й польсько-українська війна 1918-1919 рр. Польськоукраӥнські студіï. Матеріали наукової конференції. 29-31 травня 1992 р., м. КаменецьПодільський. К., 1993. С. 172-183; Цвенгрош Г. Рим і Україна: Апостольський престол і митрополит А. Шептицький у 1918-1919 рр. Дзвін. 1992. № 5-6. С. 107-113.

85 Сергійчук В. Греко-католицька церква в 1944-1991 рр. Украйнський історичний журнал. 1996. № 4 . С.101-112; Сергійчук В. Нескорена церква. Подвижництво грекокатоликів України в боротьбі за віру і державу. К.: Дніпро, 2001. 494 с.; Сергійчук В. Постать митрополита Андрея Шептицького в українському національному житті. Держсавник, мислитель, богослов: матеріали міжнародної конференції, присвяченої 60-річчю від дня смерті Митрополита Андрея Шептицького. К.: Українська видавнича спілка, 2005. С. 5-21; Сергійчук В. Українські державники: Андрей Шептицький. К., 2015. $440 \mathrm{c}$.

${ }^{86}$ Головин Р. Владика Андрей. Альманах «Гомону Украӥни». Торонто, 1994. С. 45-46.

${ }^{87}$ Ibid. C. 109. 
the author, "Metropolitan Andrey Sheptytsky becomes the greatest personality that the Sheptytsky family gives to Ukraine. He was not only the absolute and undisputed leader of the Ukrainian Church for half a century, but also the highest authority among the Ukrainian people in such difficult times of Ukrainian history. He could be called the generous gift of God's Providence to the suffering Ukrainian people" ${ }^{\sharp 8}$. The researcher made it clear that "his view is not only directed to Ukraine, although it remains his first goal. Due to the loyalty to the Ukrainian people, Metropolitan Sheptytsky wants to bring to the unity all the Eastern Christians. He intends to complete what Pociej's Union began, and, in particular, what great metropolitans from the seventeenth century, Josyf Veliamyn Rutsky and Petro Mohyla, dreamed of: a Ukrainian Patriarchate in Kyiv in connection with the whole Universal Church under the surface of Pope" ${ }^{" 89}$.

Some touches to the portrait of Sheptytsky as a politician were made by well-known foreign scientists Volodymyr Kosyk ${ }^{90}$ and Paul Robert Magocsi" ${ }^{91}$. The latter, in particular, noted that "Sheptytsky was a titanic figure (both in physique and for his socio-cultural influence), he came from a polonized Ukrainian family and, having found his Rus roots, sincerely joined the Ukrainian national camp... As a result, Greek Catholic eparchy in Galicia under the leadership of Sheptytsky gradually changed its position and in the early twentieth century became a bastion of the Ukrainian movement" (1938-1939 - Aut.) Ukrainians, led by influential Greek Catholic Metropolitan of Lviv Andrey Sheptytsky, looked at Subcarpathian Rus with a great hope" ${ }^{\circ 3}$. Andrey Sheptytsky congratulated the Transcarpathians on granting them autonomous rights by Prague, served a prayer at St. George's Church, and corresponded with Avhustyn Voloshyn. In his monograph, Canadian historian P. Stercho quotes Metropolitan's greeting letter to A. Voloshyn on the occasion of his appointment as a Prime Minister of the Government of Carpathian of Ukraine: "I'm sending my sincere wishes to you and I assure you of my daily prayers for Your Excellency and for your brothers in the Carpathians, subjected to Your power. May the Almighty take your steps and fill you with the wisdom of God from heaven so that you

\footnotetext{
${ }^{88}$ Ортинський І. Хрещення, хрест та харизма України. Дрогобич, 1993. С. 109.

${ }^{89}$ Ibid. C. 109.

${ }^{90}$ Косик В. Україна і Німеччина у Другій світовій війні. Париж - Нью-Йорк - Львів, 1993. $660 \mathrm{c}$.

${ }_{91}^{91}$ Магочій Павло Роберт. Історія України. К.: Критика, 2007. 640 с.

92 Ibid. C. 381.

93 Магочій П. Р. Формування національної свідомості: Підкарпатська Русь (18481948). Ужгород, 1994. С. 145.
} 
could lead the people, entrusted to you, to a complete freedom and versatile well-being"94. Modern Ukrainian researchers wrote more about A. Sheptytsky's attitude to Carpathian Ukraine ${ }^{95}$.

Important and interesting in all respects is the work "Metropolitan Andrey Sheptytsky", written by Richard Tozhetsky, and published in 1988. Having raised a number of complicated problems, the author elaborated on the ambiguous attitude of various political forces towards Metropolitan: "We still have an open question as to why Metropolitan did not find proper obedience among different groups of Ukrainian society. There was a nationalist underground brought up in the spirit of struggle after World War I. The process of its reorientation developed very slowly, and it did not intend to stop this struggle, in particular, as a result of an unrealistic assessment of international conditions. It was extremely difficult to fill hearts and inflammatory minds, even when it came to influencing clergy. They came primarily from the peasantry and formed the backbone of the national movement, and often nationalism, which grew up from the social and national wrongs, inflicted to Ukrainians. Such clergymen were convinced that if the Ukrainians were armed, then the Third Reich would sooner or later listen to their demands, they believed in a common interest, in ending the predatory policy towards Ukraine. To some extent, these reasons led to the approval of the actions of those priests, who were chaplains at various military units, which cooperated with or served in the Wehrmacht (this refers to the "Nachtigal", "Roland" or division "Galicia")" "96. Inspite of this, "the consolidation efforts of Metropolitan are well known to all Ukrainians" $"$. R. Tozhetsky will research these issues for

94 Стерчо П. Карпато-Українська держава: До історії визвольної боротьби карпатських українців у 1919-1939 роках. Торонто: Наукове Товариство ім. Т. Шевченка, 1965. C. 101.

95 Вегеш М. Карпатська Україна. Документи і факти. Ужгород: Видавництво „Карпати”, 2004. 432 с.; Вегеш М. Велич і трагедія Карпатської України. - Ужгород: Видавництво УжНУ «Говерла», 2007. 296 с.; Вегеш М. Карпатська Україна в портретах. Ужгород: Видавництво УжНУ «Говерла», 2007. 376 с.; Вегеш М., Токар М. КарпатоУкраїнське державотворення: До 70-річчя проголошення державної незалежності Карпатської України. Ужгород: Видавництво УжНУ «Говерла», 2009. 536 с.; Вегеш М., Токар М. Вершина духу. До 80-річчя проголошення державної незалежності Карпатської України. Ужгород: Всеукраїнське державне видавництво «Карпати», 2018. 324 с.

96 Тожецький Р. Митрополит Андрей Шептицький. Ковчег: Зб. праць 3 церковної історії. Львів, 1993. Вип.1. С. 108.

97 Тожецький Р. Митрополит Андрей Шептицький. Ковчег: Зб. праць з церковної історії. Львів, 1993. Вип. 1. С. 109. 
many times ${ }^{98}$. Modern Ukrainian researchers have repeatedly written about the activities of Metropolitan A. Sheptytsky during the World War II, including the protection of the Jewish population ${ }^{99}$. Noteworthy are the detailed monographs by Y. Kyrychuk, A. Rusnachenko and B. Yarosh ${ }^{100}$. To the deep conviction of V.-D. Hajke, Metropolitan Andrey Sheptytsky was a great supporter of the Ukrainian division "Galicia", and his close associate V. Laba "took over the spiritual care of the division and had great merit in this field. All parts of the division welcomed him gladly, and his Divine Service on great holidays would remain in a memory forever. Each regiment

98 Тожецький Р. Митрополит Андрей Шептицький і національні проблеми. Хроніка 2000. 2012. Вип. 3 (93). С. 255-275.; Тожецький Р. Митрополит Андрей Шептицький. Літопис Голготи Украӥни: Т. 2. Репресована церква. Дрогобич: Відродження, 1994. С. 29-37.

${ }^{99}$ Боляновський А. Дивізія «Галичина»: історія. Львів, 2000. 528 с.; Боляновський А. Між християнською мораллю i нелюдським злом (реакція митрополита Андрея Шептицького на окупаційну політику націонал-соціалістичної Німеччини в Галичині у 1941-1944 рр.: від формальної лояльності до критики і протестів). Друга світова війна та долі мирного населення у Східній Європі. К., 2016. С. 7-70; Боцюрків Богдан. ГрекоКатолицька Церква і Радянська держава (1939-1950) / переклад з англійської Наталії Кочан, за редакцією Олега Турія. Львів: Видавництво Українського Католицького Університету, 2005. хx + 268 с.; Геник Л. Діяльність митрополита А. Шептицького в Галичині в період Другої світової війни. Карпати: людина, етнос, иивілізація. 2012. Аип. 4. С. 129-136; Гунчак Т. Україна: XX століття. К.: Дніпро, 2005. 384 с.; Гуркіна С. Митрополит Андрей (Шептицький) у період німецької окупації Галичини: найновіша історіографія питання (1989-2000 роки). Ковчег. Львів, 2001. Ч. 3. С. 563-565; Клюнь Р. Діяльність митрополита Андрея Шептицького часів Другої світової війни в українській історіографії. Інтелігенція $i$ влада. Матеріали 5-ї Всеукраїнської наукової конференції. Одеса, 2009. Ч. 3. С. 99-106; Крупа Л. Діяльність УГКЦ в час німецької окупації 31941 по 1944 роки. Тернопільський комериійний інститут. Наукові записки "Матеріали досліджень викладачів інституту, проведені у 2000 та 2001 роках". Тернопіль: ТКІ, 2002. С.129-136; Крупа Л. Діяльність УГКЦ під час німецької окупації України з 1941 по 1944 роки. Наукові записки: Збірник наукових статей Начіонального педагогічного університету імені М.П. Драгоманова / Укл. П.В.Дмитренко, О.Л.Макаренко. К: НПУ, 2000. Ч.3. С.160-171; Крупник Л. Дискредитація Митрополита Андрея Шептицького та УГКЦ як практика радянської влади. Друга світова війна та долі мирного населення у Східній Європі. Матеріали міжнародної наукової конференції памяті Митрополита Андрея Шептицького. 30 листопада-1 грудня 2015 року, м. Київ / За ред. Леоніда Фінберга. К.: Дух і Літера, 2016. С. 111-122; Лисенко О.С. До питання про становище церкви в Україні у період Другої світової війни. Украӥнський історичний журнал. 1995. №3. С.73-81.

${ }^{100}$ Киричук Ю. Український національний рух 40-50 років ХХ століття: ідеологія та практика. Львів: Добра справа, 2003. 464 с.; Русначенко А. М. Народ збурений: Національно-визвольний рух в Україні й національні рухи опору в Білорусії, Литві, Латвії, Естонії у 1940-50-х роках. К.: Універсальне видавництво «Пульсари», 2002. 519 с. + іл.; Ярош Б.О. Сторінки політичної історії західноукраїнських земель (30 - 50-ті pp. ХХ ст.). Луцьк: Редакційно-видавничий відділ "Вежа" ВДУ ім. Л. Українки, 1999. 184 с.; Ярош Б.О. Тоталітарний режим на західноукраїнських землях, 30 - 50-ті роки XX ст. (історико-політологічний аспект). Луцьк: Надстирря, 1995. 176 с. 
and ceparate kurin of the division had their own priests, who were subordinate to the high priest Mykhailo Leventz in the division headquarters. The Divine Services for the soldiers were served every Sunday and every holiday..." ${ }^{101}$. P. Mirchuk wrote about the relationship between A. Sheptytsky and the leaders of the OUN: Metropolitan "confided the OUN in the ZUZ (Western Ukrainian lands - Aut.) about the agreement between Germany and USSR to the occupation of Western Ukrainian lands by the Bolsheviks - in case of Poland's defeat» ${ }^{102}$. T. Hunchak wrote about Sheptytsky's activity as a chairman of the Ukrainian National Council, which he embraced after the death of K. Levytsky. The historian stated: "But under the German occupation even the authority of Metropolitan did not help. On March 4, 1942, a representative of the security service declared that the National Council is impossible to be active any more. The reason for this was the signing of a memorandum in defense of the rights of Ukraine by Metropolitan Sheptytsky. But it was just an occasion to finally end the Ukrainian National Council. The Germans demanded its dissolution, but Metropolitan Sheptytsky only stopped its activities"103.

Among the works of the Ukrainian researchers, the work of a scientist from Ivano-Frankivsk, professor J.Yu. Zaborovsky deserves attention. His book "Metropolitan Andrey Sheptytsky. An Essay on the Life and Service to the Church and to the People (1865-1944)" was published in 1995. The author briefly described the main periods of life and activity of Andrey Sheptytsky, analyzed his views. One can not disagree with the author's statement that "glorious personalities are like high mountains whose snowwhite peaks can be seen for many kilometers, because their heights cannot be covered with the trees or the folds of the earth's surface. Metropolitan Andrey Sheptytsky certainly deserved to be called glorious, because there is virtually no part of Galicia's socio-political life in the twentieth century, where we have not met with deeds or at least significant influence of his personality. Equal to him church or secular figures can be found only in the XVIII century, for example, Viniamin Rutsky - Metropolitan of Kyiv; and even in the X-XIII centuries. Among the kniazs are Volodymyr the Great, Danylo Halytsky. It is no wonder, then, that Metropolitan Sheptytsky has been called for a long time - not very successfully from the philosophical point of view, but quite normally from the historical

${ }^{101}$ Гайке Вольф-Фрідріх. Українська Дивізія «Галичина». Історія формування і бойових дій у 1943-1945 роках / за заг. ред. В. Кубійовича. Тернопіль: Мандрівець, 2018. С. 32.

102 Мірчук П. Нарис історії Організації Українських Націоналістів. Т. 1. 1920-1939. Мюнхен - Лондон - Нью-Йорк, 1968. С. 585.

${ }^{103}$ Гунчак Т. Україна: XX століття. К.: Дніпро, 2005. С. 220. 
perspective - "Kniaz of the Church"104. The famous historian of the Greek Catholic Church V. Marchuk, basing on the huge source material, researched the promotional activity of Metropolitan of Galicia more deeply $^{105}$.

The promotional activity of Metropolitan Andrey Sheptytsky was highly appreciated by the historian-theologian K. Panas. In his deep conviction, Sheptytsky is one of the most striking figures in our history, whose name will be inducted into the list of the Holy Fathers-Confessors of the Ukrainian Catholic Church. The researcher identifies two important matters that the Galician Metropolitan has accomplished: "Metropolitan has devoted all his life and all his genius to the competition for the Ukrainian Church, the spiritual stronghold of the Ukrainian nation, which could not be destroyed by all the forces of the world and hell. The second thing that this genius of our history dedicated his life to was the restoration of the Ukrainian Kyiv Metropolitanate within its existence during the Kyiv kniazs era and the proclamation of the Ukrainian Patriarchate. Unfortunately, adverse political developments in Europe have hindered the accomplishment of this great case" ${ }^{\text {106 }}$.

Describing the various activities of Sheptytsky, Mykola Bereslavsky highlighted Metropolitan's attitude to the development of Ukrainian culture - collecting ancient monuments, helping Ukrainian artists, creating gymnasiums and more. In the deep conviction of the researcher, "Bishop Andrey was a great humanist, philanthropist, he advocated social justice, helped the poor, needy. This is evidenced by his words and deeds" 107 . These issues are researched in the ground works of M. Bandrivsky, O. Haidukevych, N. Kontsur-Karabinovych, S. Hnot, B. Holovyn, N. Hrecheniuk, H. Huchko, O. Kekosh, M. Kryvenko, L. Krupa, H. Kurys,

104 Заборовський Я. Ю. Митрополит Андрей Шептицький. Нарис про життя i служіння народові (1865-1944 рр.). Івано-Франківськ, 1995. С. 5.

105 Марчук В. В. Українська греко-католицька церква в суспільному житті України XX ст. Автореферат дис... доктора іст. наук. Спеціальність 07. 00. 01. Чернівці, 2004. 35 с; Марчук В. Українська Греко-Католицька Церква: історичний нарис. Івано-Франківськ: Плай, 2004. 464 с; Марчук В. Церква в умовах релігійного підпілля: вибір українських греко-католиків у (1941-1946 pp.). Галичина: науковий i культурно-просвітній краєзнавчий часопис. 2008. №14. С.248-255; Марчук В.В. Греко-католицька церква в умовах німецького та радянського тоталітаризму (1941-1946). Галичина: науковий i культурно-просвітній краєзнавчий часопис. 2000. № 4. С.66-72; Марчук В.В. Українська греко-католицька церква: історичний нарис. Івано-Франківськ: Плай, 2001. 164 с; Марчук В.В. Церква, духовність, нація. Українська греко-католицька церква в суспільному житті України XX ст. Івано-Франківськ: Плай, 2004. 464c.

${ }^{106}$ Панас К. Історія Української Церкви. Львів, 1992. С. 132.

${ }^{107}$ Береславський М. 3 історії Української Греко-Католицької Церкви. Книга 2. Львів, 1992. C. 31. 

P. Lazechko, L. Lazechko, L. Roshchyna, N. Rusko ${ }^{108}$.
H. Lytvyn, O. Ohirko, O. Pasitska,

${ }^{108}$ Бандрівський М. С. Пам'яткоохоронна діяльність Андрея Шептицького. Записки Львів. наук. б-ки ім. В. Стефаника. Л., 2006. Вип.7/8. С. 459-467; Гайдукевич О. Митрополит Андрей Шептицький - природоохоронний діяч Галичини. Схід. № 1 (141). Січень-лютий 2016. С. 35-39; Гайдукевич О., Концур-Карабінович Н. Митрополит Андрей Шептицький та охорона природи Галичини. Науковий вісник Чернівецького начіонального університету імені Юрія Федьковича. Серія Історія. 2016. № 2. С. 20-26; Гайковський М. Велике протистояння: опір Греко-Католицької Церкви більшовицькому Гнот С. Греко-католицька церква і мистецтво Західної України 20-30-pp. ХХ ст. Науковий вісник Волинського держсавного університету імені Лесі Украӥнки. Серія - історичні науки. Луцьк: Вид.-во ВДУ, 2001. С. 44-48; Гнот С. Греко-католицька церква і організація суспільної опіки Галичини (1921-1939). Актуальні проблеми державного управління. Збірник наукових праць / Львівський філіал Української Академії державного управління при Президентові України. Львів: Вид.-во ЛФ УАДУ, 2001. Вип. 6. С. 299-309; Гнот С. Греко-католицька церква i проблема збереження пам'яток національної культури Галичини у міжвоєнний період. Історичні пам ятки Галичини. Матеріали наукової краєзнавчої конференції 21 листопада 2002 р. Львів: Видавничий центр ЛНУ імені Івана Франка, 2003. С. 126-135; Гнот С. До питання про діяльність Греко-католицької церкви у створенні захистів та захоронок у Галичині в міжвоєнний період. Історія релігій в Україні. Праці XI-ї Міжнародної наукової конференції (Львів, 16-19 травня 2001 року). Львів: “Логос", 2001. Кн. 1. С. 179-183; Гнот С. Доброчинна діяльність Греко-католицької церкви у 20-30-х рр. XX ст. (за матеріалами української галицької преси). Наукові зошити історичного факультету Львівського начіонального університету імені Івана Франка. Збірник наукових праць. Львів: ЛНУ імені Івана Франка, 2003. Вип. 5-6. С. 211-219; Гнот С. І. Доброчинна діяльність греко-католицької церкви у 1921-1939 pр. (за матеріалами Галицької митрополії). Автореферат дис. ... канд. іст. наук. Спеціальність 07.00.01 - Історія України. Львів, 2003. 22 с.; Гнот С. Митрополит Андрей Шептицький і розвиток національної культури Галичини в міжвоєнний період. Історія релігій в Україні. Праці XII-ї Міжнародної наукової конференції (Львів, 20-24 травня 2002 року). Львів: “Логос", 2002. Кн. 1. С. 113-117; Гнот С. Проблема захисту дітей в діяльності Грекокатолицької церкви міжвоєнного періоду. Вісник Львівської комериійної академії. Серія гуманітарні науки. Львів: Вид.-во ЛКА, 2002. Вип. 4. С. 54-66; Гнот С. Роль Грекокатолицької церкви у суспільно-політичному житті Західної України 20-30-х років XX ст. Українське державотворення: уроки, проблеми, перспективи. Матеріали науковопрактичної конференції 22 листопада 2001 року. Львів: ЛФ УАДУ, 2001. Ч. 1. С. 107-109; Гнот С. Співпраця Греко-католицької церкви Львівської архієпархії з українським шкільництвом у період між двома світовими війнами. Мандрівець / Видання Національного університету “Києво-Могилянська академія”. Тернопіль, 2002. №3 (38). С. 13-19; Головин Б. Митрополит Андрей Шептицький - благодійник «Просвіти». Збірник праць. Тернопіль, 2006. Т. 2. С. 98-100; Греченюк Н. Культурно-освітня діяльність митрополита Андрея Шептицького. Украӥна - Свропа - Світ. Міжнародний збірник наукових праць. Серія: Історія, міжнародні відносини. 2013. Вип. 12. С. 272-275; Гучко Г. Андрей Шептицький як меценат української культури. Соціогуманітарні проблеми людини. Журнал. 2015. № 8. С. 87-94; Кекош О. М. Виховання молоді крізь призму педагогічних поглядів митрополита Андрея Шептицького. Педагогічні науки. 2013. Вип. 112. С. 53-59; Кекош О. М. Просвітницька діяльність митрополита Андрея Шептицького в контексті духовного становлення сучасної молоді. Наукові записки Тернопільського начіонального педагогічного університету імені Володимира Гнатюка. 
Metropolitan Andrey Sheptytsky closely followed the processes that took place in Transcarpathia. Uzhgorod historians dedicated their works to this issue $^{109}$. An essay and memoirs about Andrey Sheptytsky were published by the famous Ukrainian scientist from Ivano-Frankivsk, professor Volodymyr Hrabovetsky ${ }^{110}$. Although N. Kontsur-Karabinovych investigated the liquidation of the Greek Catholic Church in Western Ukraine (Lviv Council in 1946), her publications contain extensive factual material about

Серія Педагогіка. Тернопіль: ТНПУ, 2013. № 1. С. 25-30; Кривенко М. О. Книгозбірня «Студіону» у Львові (1909-1940): Історія, сучасний стан фонду. Автореферат дис. ... канд. іст. наук. Спеціальність 27.00.03 - Книгознавство, бібліотекознавство, бібліографознавство. К., 2010. 23 с.; Крупа Л. Створення та діяльність закладів для сиріт під патронатом митрополита Андрея Шептицького. Наукові записки Тернопільського державного педагогічного університету імені Володимира Гнатюка. Серія: Історія / За заг. ред. проф. М.М. Алексієвця. Тернопіль: Літопис. 2003. Вип.1. С.73-76; Курис Г. Митрополит Андрей Шептицький: «Добре робите, що дбаєте про освіту і знання»: (Життєвий і творчий шлях А. Шептицького). Освітянин. 1996. № 4. С. 27; Лазечко П., Лазечко Л. Меценати української культури: (Митрополит Андрей Шептицький). Дзвін. 2003. № 11-12. С. 133-137; Литвин Г. Роль митрополита Андрея Шептицького у розвитку мистецтва Галичини. Науковий вісник Івано-Франківського Богословського університету імені св. Івана Золотоустого «Добрий Пастир». Богослівя. Збірник наукових праць. Випуск 8. Івано-Франківськ, 2015. С. 324-329; Огірко О. Митрополит Андрей Шептицький - славетний український педагог, опікун і меценат освіти. Науковий вісник Івано-Франківського Богословського університету імені св. Івана Золотоустого "Добрий Пастир». Богослівя. Збірник наукових праць. Випуск 8. Івано-Франківськ, 2015. С. 61-70; Пасіцька О. Андрей Шептицький у контексті суспільно-економічного розвитку Галичини 20-30-х років XX ст. Науковий вісник Івано-Франківського Богословського університету імені св. Івана Золотоустого "Добрий Пастир». Богослівя. Збірник наукових праць. Випуск 8. Івано-Франківськ, 2015. С. 71-77; Пасіцька О. І. Вплив митрополита Андрея Шептицького на господарське життя галицьких українців (кінець XIX - перша третина ХХ ст.). Гілея. 2014. Вип. 105 (2). С. 31-35; Рощина Л. О. Меценатська діяльність митрополита Андрея Шептицького. Наука. Релігія. Суспільство. 2008. № 1. С. 178-180; Руско Н. Роль митрополита Андрея Шептицького у збереженні сакральної спадщини галичан. Науковий вісник Івано-Франківського Богословського університету імені св. Івана Золотоустого "Добрий Пастир». Богослівя. Збірник наукових праць. Випуск 8. Івано-Франківськ, 2015. С. 330-337.

${ }^{109}$ Майороші М. А. Митрополит Андрей Шептицький і Закарпаття. Науковий вісник Ужггородського університету. Серія Історія. Вип. 2012. С. 18-27; Вегеш М. Могутня постать української історії: [Про Митрополита Андрея Шептицького]. Календар «Просвіти» на 1995 рік / Закарп. крайове т-во «Просвіта»; [Упорядн.: П.Федака, Й.Баглай]. Ужгород: МПП «Гражда», 1995. С.142-144; Басараб В., Вегеш М. Дві постаті 3 історії української церкви: Андрей Шептицький і Августин Волошин. Ужгород: Видавництво УжНУ «Говерла», 2011. 210 с; Басараб В., Вегеш М. Життя і помисли митрополита Андрея Шептицького. Ужгород, 2003. 112 с.

110 Грабовецький В. Ілюстрована історія Прикарпаття. Тисячолітній літопис Гуцульщини. Т. 3. Видання друге, доповнене. Івано-Франківськ: Видавництво «Нова Зоря», 2004. 464 c.

Грабовецький В. Історія Івано-Франківська (Станіславова). 3 найдавніших часів до початку XX століття. Частина 1. Івано-Франківськ: Нова Зоря, 1999. 304 с. 
A. Sheptytsky's recent life and activities ${ }^{111}$. The multifaceted sociopolitical activity of Metropolitan of Galicia through the prism of jurisprudence was investigated by N. Prokop ${ }^{112}$.

${ }^{111}$ Концур Н. Ліквідація греко-католицької церкви на Станіславівщині. Краєзнавець Прикарпаття. Івано-Франківськ, 2007. №10. С. 59-61; Концур Н. Львівський собор 1946 року і проблеми виживання греко-католиків. Наукові записки. Серія: Історія. Вип. 3. Тернопіль, 2008. С.268-271; Концур Н. Львівський собор 1946 року та його місце в історії УГКЦ. Наукові записки. Серія: Історія. Вип. 2. Тернопіль, 2006. С.55-59; Концур Н. Наслідки Львівського Собору і їх вплив на систему міжнародних і міжцерковних відносин УГКЦ. Етнос. Культура. Духовність. Чернівці, 2006. Ч.2. С.93-100; Концур Н. Патріарх Йосиф Сліпий: штрихи до портрета релігійного діяча. Галичина: науковий і культурно-просвітній краєзнавчий часопис. Івано-Франківськ, 2008. №14. С.397-400; Концур Н. Підготовка до ліквідації Української греко-католицької церкви в Галичині. Література і культура Полісся. Вип.27.: Регіональна історія та культура в українському та східноєвропейському контексті. Ніжин, 2004. С.163-167; Концур Н. Становище Української греко-католицької церкви після відновлення радянської влади в західній Україні. Мандрівець: Всеукраїнський науковий журнал. Тернопіль, 2006. № 6. С. 14-17; Концур-Карабінович Н. Антиунійна політика комуністичного режиму щодо грекокатолицької церкви у 1940-х рр. Наукові записки Тернопільського національного педагогічного університету імені Володимира Гнатюка. Серія Історія. 2015. Вип. 2. Ч. 2. С. 38-42; Концур-Карабінович Н. Греко-католицька церква. Початки підпілля. ІваноФранківськ: Нова зоря, 2011. 220 с.; Концур-Карабінович Н. Постать митрополита Андрея Шептицького в антиунійній політиці радянської влади. Науковий вісник ІваноФранківського Богословського університету імені св. Івана Золотоустого "Добрий Пастир». Богослівя. Збірник наукових праць. Випуск 8. Івано-Франківськ, 2015. С. 243-249; Концур-Карабінович Н. Репресивні заходи радянської влади стосовно грекокатолицької церкви після смерті Митрополита Андрея Шептицького. Науковий вісник Чернівецького національного університету імені Юрія Федьковича. Серія Історія. 2016. № 1. С. 56-61.

112 Прокоп Н. М. Державно-правові погляди митрополита Андрея Шептицького. Автореферат дис. ... канд. юрид. наук. Спеціальність 12.00.01 - Теорія та історія держави і права; історія політичних і правових вчень; 081 - Право. Харків, 2017; Прокоп Н. М. Дослідження проукраїнської державницької діяльності митрополита А. Шептицького кінця XIX - початку XX ст. Право, суспільство, держава: Форми взаємодіï. Матеріали Міжнародної науково-практичної конференції. 15-16 січня 2016 р. Київ, 2016. С. 14-16; Прокоп Н. М. Духовність як засада української державності в доктрині А. Шептицького. Право як ефективний суспільний регулятор. Матеріали Міжнародної науково-практичної конференції. 19-20 лютого 2016 р. Львів, 2016. С. 12-14; Прокоп Н. М. Концепт державності у політико-правових поглядах Андрея Шептицького. Правоохоронна функиія держави: теоретико-методологічні та історико-правові проблеми. Матеріали Міжнародної наукової конференції. 13 листопада 2015 р. Харків, 2015. С. 239-241; Прокоп Н. М. Правове бачення митрополитом А. Шептицьким українських християнських церков у розбудові національної держави. Сучасні тенденції розвитку науки. Матеріали Міжнародної науково-практичної конференції (15-16 березня 2017 р., м. Київ). Київ, 2017. С. 81-83; Прокоп Н. М. Роль А. Шептицького в утвердженні загального виборчого права та національних інтересів українців в Австро-Угорщині. Держава $i$ право: проблеми становлення і стратегія розвитку. Матеріали Міжнародної науковопрактичної конференції. 25-26 грудня 2015 р. Ужгород, 2015. С. 22-25; Прокоп Н. М. Характеристика діяльності політичних партій А. Шептицьким в українському 
Special attention undoubtedly deserves a monograph "The State-making Concept and National-Patriotic Ideas of Metropolitan Andrey Sheptytsky", written by Volodymyr Basarab ${ }^{113}$. The author is well known in the scientific circles for his publications on the state-making activity of Metropolitan ${ }^{114}$.

державотворенні другої половини XIX ст. Рівень ефективності та необхідність впливу юридичної науки на нормотворчу діяльність та юридичну практику. Матеріали Міжнародної науково-практичної конференції. 5-6 лютого 2016 р. Харків, 2016. С. 9-11; Прокоп Н. Методологічні засади дослідження проукраїнської державницької діяльності А. Шептицького. Право і суспільство. 2015. № 6. Ч. 3. С. 35-40; Прокоп Н. Митрополит А. Шептицький в українському державотворенні 20-30-х років XX століття. Актуальні проблеми держави і права. 2016. №76. С. 159-163; Прокоп Н. Обрис проукраїнської державницької діяльності А. Шептицького. Право $і$ безпека. 2015. № 3 (58). С. 35-41; Прокоп Н. Парламентаризм і виборче право в теоретичній спадщині митрополита А. Шептицького. Науковий вісник Міжнародного гуманітарного університету. Серія Юриспруденція. Випуск 17. Т. 1. 2015. С. 60-63; Прокоп Н. Роль А. Шептицького в історії українського державотворення кінця XIX - першої половини XX ст. Бюлетень Міністерства юстиції України. 2016. № 1. С. 28-33.

${ }^{113}$ Басараб В. Державотворча концепція та національно-патріотичні ідеї митрополита Андрея Шептицького. Ужгород: Гражда, 2019. 232 с.

${ }^{114}$ Басараб В. Державницькі ідеї Андрея Шептицького в період Другої світової війни: концепція незалежності України та засудження політики Гітлера. IX Міжнародний конгрес україністів. Історія. Збірник наукових статей. НАН України, ІМФЕ ім. Рильського. Київ, 2018. С. 145- 157; Басараб В. Державотворчі та патріотичні ідеї А. Шептицького в історичному контексті. Науковий вісник Ужгородського університету. Серія: Історія. Вип. 2(39). Ужгород: «Говерла», 2018. С. 11-20; Басараб В. Моделі державотворення у працях А. Шептицького. Науковий вісник Ужсородського університету. Серія: Історія. Вип. 1(38). Ужгород: «Говерла», 2018. С. 11-18; Басараб В. Національно-патріотичні ідеї А. Шептицького [на основі праці «Пересторога перед комунізмом»]. Держава у теорії і практиці українського наиіоналізму. Матеріали VI Всеукраїнської конференції з міжнародною участю. Івано-Франківськ, 26-27 червня 2015 р. / Наук. ред. О. М. Сич. Івано-Франківськ: Місто НВ, 2015. С. 16-27; Басараб В. Осмислення А. Шептицьким сценарію більшовицького перевороту в Іспанії (на основі передмови А.Шептицького до «Пасторського послання еспанських єпископів»). Матеріали II Міжнародної науково-практичної е-конферениї «Мультидисииплінарні академічні дослідження і глобальні інноваиії: гуманітарні та соиіальні науки» (MARGIHSS 2016), 28-29 липня 2016 року, м. Київ). Київ, КНЛУ, 2016. С. 22-24; Басараб В. Перспективи та реалії становлення незалежної України крізь призму політичних ідей А.Шептицького. Економічні, політичні та культурологічні аспекти європейської інтеграчї Украӥни в умовах нових глобалізацій них викликів: матеріали доповідей Міжнародної науково-практичної конференції (м. Ужсгород, 16-17 квітня 2018 року). Ужгород: «Гельветика», 2018. С. 355-359; Басараб В. Проблема єдності Церков у світлі екуменічних ідей митрополита А.Шептицького. Матеріали міжнародної науково-практичної конферениї Волинської православної богословської академії УПЦ КП «Державотворення і помісність Церкви: історичні прочеси та сучасні реалї» (18.05.2017). Луцьк: Видавництво Волинської православної богословської академії EIK' $\Omega \mathrm{N}$, 2017. С. 27-34; Басараб В. Революційні процеси 1917-1921 рр. в Україні крізь призму послань митрополита Андрея Шептицького. Література та культура Полісся. Вип. 87. Серія «Історичні науки». № 7. Ніжин: НДУ ім. Гоголя, 2017. С. 130-140; Басараб В. Роль Грекокатолицької церкви у процесі становлення української державності (на матеріалі послань та листів Андрея Шептицького). Карпатська Украӥна - незалежна держава. Матеріали 
The monograph analyzes in detail 62 documents, showing a clear civicpatriotic position and, according to the author, the "political competence" of Andrey Sheptytsky, who throughout his life was a rational diplomat, and who realistically treated the historical circumstances and foreign policy of the states, that influenced the life of the Ukrainian nation. The analyzed pastoral messages, letters, memorandums and other documents helped the scientist to trace the evolution of the state-building ideas of Metropolitan of Galicia, to see him not only as a prominent church figure, but also as a diplomat, who is capable of making important, complex, and sometimes compromising decisions for the good of his people. V. Basarab argued with good reason that many arguments of the Metropolitan of Galicia echo the reality of modern Ukraine, concern the problems of state formation, unity of the Ukrainian people at the spiritual, social and political level. In his numerous speeches Andrey Sheptytsky emphasized the need to build a new Ukraine, based on the Christian morality and patriotism. Throughout his life he sought to establish Ukraine as an independent state among other European countries.

Metropolitan Andrey Sheptytsky's life path and rich creative heritage have also been reflected on the pages of collective monographs and in various encyclopedic publications ${ }^{115}$. M. Marynovych's monograph contains a thorough analysis of the preaching heritage of Metropolitan Andrey

міжнародної конференції, присвяченої 80-річчю проголошення незалежності Карпатської України. Ужгород, видавництво ПП «Аутдор-Шарк», 2019. С. 129-140.

115 Нариси 3 історії дипломатії України / О. І. Галенко, Є. Є. Камінський, М. В. Кірсенко та ін., під ред. В. А. Смолія. К.: Видавничий дім «Альтернативи», 2001. 736 с.; Політична історія України. ХХ ст.: У 6 т. / Редкол. І. Ф. Курас (голова) та ін. Т. 4: Україна у Другій світовій війні. 1939-1945. Керівник тому В. І. Кучер. К.: Генеза, 2003. 584 с.; Політична історія України. ХХ ст.: У 6 т. / Редкол. І. Ф. Курас (голова) та ін. Т. 5: Українці за межами УРСР (1918-1940). Керівник тому В. П. Трощинський. К.: Генеза, 2003. 720 с.; Політична історія України. ХХ ст.: У 6 т. / Редкол.: І. Ф. Курас (голова) та ін. Т. 1: На зламі століть (кінець ХІХ ст. - 1917 р.) / Ю. А. Левенець (кер.), Л. П. Нагорна, М. С. Кармазіна. К.: Генеза, 2002. 424 с.; Політичний терор і тероризм в Україні. XIXXX ст. Історичні нариси / [Д.В.Архієрейський, О.Г.Бажан, Т.В.Бикова та ін. Відп. ред. В.А.Смолій]. К.: Наукова думка, 2002. 952 с.; Україна крізь віки: Т. 10. Рубльов О. С., Реєнт О. П. Українські визвольні змагання 1917-1921 рр. К.: Видавничий Дім «Альтернативи», 1999. 320 с.; Україна крізь віки: Т. 11. Кульчицький С. В. Україна між двома війнами (1921-1939рр.). К.: Видавничий Дім «Альтернативи», 1999. 336 с.; Україна крізь віки: Т. 12. Коваль М. В. Україна в другій світовій і Великій Вітчизняній війні (1939-1945рр.). К.: Видавничий Дім «Альтернативи», 1999. 336 с.; Україна: політична історія. XX - початок XXI ст. / Редрада: В. М. Литвин (голова) та ін. Редкол.: В. А. Смолій, Ю. А. Левенець (співголови) та ін. К.: Парламентське вид-во, 2007. 1028 с.; Шуст Р. Шептицький Андрей. С. 1085-1087. Довідник з історії України (A - Я): Посібн. для середн. загальноос. навч. закл. / За заг. ред. І. Підкови, Р. Шуста. 2-ге вид., доопр. і доповн. К.: Генеза, 2001. 1136 с. 
Sheptytsky in terms of its accordance (or inconsistency) with the methodological principle, nowadays called "positive sum". Metropolitan derives the genesis of this way of thinking from theology, and the author finds examples of its use in the messages of Kyr Andrey in the field of economic relations, national relations, state building, interfaith and interreligious relations ${ }^{116}$. Positive is also the fact that Ukrainian scientists have defended a number of dissertations in the recent years ${ }^{117}$.

Thus, the writings of foreign and national historians give high praise to the ascetic activity of Metropolitan of Galicia Andrey Sheptytsky. Historians have emphasized his great contribution to the development of the Greek Catholic Church and culture in Galicia, raising the level of national consciousness of the entire Ukrainian people.

\footnotetext{
116 Маринович М. Митрополит Андрей Шептицький і принцип «позитивної суми». Львів: Видавництво Старого Лева, 2019. 248 с.

${ }^{117}$ Безпалько У. І. Інституалізація католицької церкви Східного обряду в Росії (19011917 рр.). Автореферат дис. ... канд. іст. наук. Спеціальність 07.00.02 - Всесвітня історія. Тернопіль, 2018. 20 с.; Білас Я. І. Митрополит Андрей Шептицький і проблеми національно-визвольного руху українців. Автореферат дис. ... канд. іст. наук. Спеціальність 09.00.11 - Релігієзнавство. К., 2003. 20 с.; Бліхар В. С. Соціальнофілософські погляди Андрея Шептицького. Автореферат дис. ... канд. філософ. наук. Спеціальність 09.00.05 - Історія філософії. Львів, 2006; Гладка Г. Л. Суспільно-політична діяльність митрополита Андрея Шептицького (1899-1939 рр.). Автореферат дис. ... канд. іст. наук. Спеціальність 07.00.01 - Історія України. Чернівці, 2000. 20 с.; Гнідик I. I. Початки та розбудова греко-католицької церкви у США (кінець XIX - початок XX ст.). Автореферат дис. ... канд. іст. наук. Спеціальність 07.00.02 - Всесвітня історія; Гнот С. І. Доброчинна діяльність греко-католицької церкви у 1921-1939 pp. (за матеріалами Галицької митрополії). Автореферат дис. ... канд. іст. наук. Спеціальність 07.00.01 Історія України. Львів, 2003. 22 с.; Кривенко М. О. Книгозбірня «Студіону» у Львові (1909-1940): Історія, сучасний стан фонду. Автореферат дис. ... канд. іст. наук. Спеціальність 27.00.03 - Книгознавство, бібліотекознавство, бібліографознавство. К., 2010. 23 с.; Крупа Л. Л. Вплив митрополита Андрея Шептицького на суспільне і культурно-просвітницьке життя в Галичині кінця XIX - першої половини XX століття. Автореферат дис. ... канд. іст. наук. Спеціальність 07.00.01 - Історія України. Чернівці, 2003. 21 с.; Прокоп Н. М. Державно-правові погляди митрополита Андрея Шептицького. Автореферат дис. ... канд. юрид. наук. Спеціальність 12.00.01 - Теорія та історія держави і права; історія політичних і правових вчень; 081 - Право. Харків, 2017; Скіра Ю. Р. Участь монахів Студійського уставу у порятунку євреїв на території Львівської архієпархії греко-католицької церкви у 1942-1944 рр. Автореферат дис. ... канд. іст. наук. Спеціальність 07.00.01 - Історія України. Львів, 2018. 20 с.; Сурмач О. І. Грекокатолицька церква в період німецького окупаційного режиму в Україні (1941-1944рр.). Автореферат дис. ... канд. іст. наук. Спеціальність 07.00.01 - Історія України. Львів, 2001. 23 с.; Шеремета О. Ю. Етичні ідеї Андрея Шептицького у релігійно-філософському контексті кінця XIX - першої половини XX ст. Автореферат дис. ... канд. філософ. наук. Спеціальність 09.00.05 - Історія філософії. К., 2010. 20 с.
} 